\title{
MAML2 wt Allele
}

National Cancer Institute

\section{Source}

National Cancer Institute. MAML2 wt Allele. NCI Thesaurus. Code C95457.

Human MAML2 wild-type allele is located in the vicinity of 11q21 and is approximately 365

$\mathrm{kb}$ in length. This allele, which encodes mastermind-like protein 2 , is involved in the modulation of Notch signaling-dependent gene expression. A translocation t(11;19)

(q21;p13) involving this gene and the CRTC1 gene is associated with mucoepidermoid carcinomas, benign Warthin tumors and clear cell hidradenomas. 